\title{
New populations of pampas deer Ozotoceros bezoarticus discovered in threatened Amazonian savannah enclaves
}

\author{
Daniel G. Rocha, Alexandre Vogliotit, Diogo M. Gräbin \\ Wilhan R. C. Assunção, Bruno Contursi Cambraia, Ana Rafaela D’Amico \\ Antonio Elson Portela and Rahel Sollmann
}

\begin{abstract}
The savannah enclaves (i.e. patches) in the southern Brazilian Amazonia are among the most threatened and poorly surveyed sites in Amazonia. As part of an extensive mammal survey, we set camera traps in three of these savannah enclaves. We obtained 23 independent records of pampas deer Ozotoceros bezoarticus, a medium sized Neotropical cervid that is strongly associated with open habitats and categorized as Vulnerable on the Brazilian Red List of threatened species. These savannah enclaves with confirmed populations of pampas deer lie outside the species' previously presumed historical range and are at least $350 \mathrm{~km}$ from any known extant population. Together, these savannah enclaves add c. 4,000 $\mathrm{km}^{2}$ to the pampas deer's currently known range. The small pampas deer populations in these enclaves are probably isolated by a matrix of Amazon forest, raising questions about spatial genetic structure and meta-population dynamics, and making them vulnerable to local extinction. We highlight the need for further studies, particularly genetic, to assess the conservation status of these populations, the results of which could potentially inform management decisions in other areas of the heavily fragmented range of this species.
\end{abstract}

Keywords Brazil, camera trap, isolated population, Neotropical cervid, Ozotoceros bezoarticus, pampas deer, savannah, southern Amazonia

DANIEL G. Rocha (Corresponding author, (D) orcid.org/0000-0002-0100-3102)* Graduate Group in Ecology, Department of Wildlife, Fish, and Conservation Biology, University of California, Davis, California, USA

E-mail rochadg.bio@gmail.com

AleXANdRe Vogliotti Instituto de Ciências da Vida e da Natureza, Universidade Federal da Integração Latino Americana, Foz do Iguacu, Brazil

Diogo M. GräBiN ${ }^{\dagger}$ Grupo de Pesquisa em Ecologia e Conservação de Felinos na Amazônia, Instituto de Desenvolvimento Sustentável Mamirauá, Tefé, Brazil

Wilhan R. C. Assunç̧ão, Bruno Contursi Cambraia, Ana Rafaela D’Amico and Antonio Elson Portela Instituto Chico Mendes de Conservação da Biodiversidade, Brasilia, Brazil

Rahel Sollmann Department of Wildlife, Fish, and Conservation Biology, University of California, Davis, California, USA

${ }^{*}$ Also at: Grupo de Pesquisa em Ecologia e Conservação de Felinos na Amazônia, Instituto de Desenvolvimento Sustentável Mamirauá, Tefé, Brazil

${ }^{\dagger}$ Also at: Programa de Pós Graduação em Ecologia e Conservação da Biodiversidade, Universidade Estadual de Santa Cruz, Ilhéus, Brazil

Received 21 September 2018. Revision requested 26 November 2018. Accepted 6 December 2018. First published online 13 August 2019.
Supplementary material for this article is available at https://doi.org/10.1017/So030605318001539

$T$ he South American savannah is the largest and most L biodiverse tropical savannah (Cardoso Da Silva \& Bates, 2002). Most of this biome, known as cerrado, is located in central Brazil, and is categorized as one of 25 global conservation hotspots (Myers et al., 2000). More than $80 \%$ of the cerrado has been cleared and only $7.5 \%$ lies within protected areas (Strassburg et al., 2017). Significant patches of savannah, known as enclaves, can also be found on the periphery of the Amazon forest. These enclaves are heterogeneous mosaics of open areas and forest with a highly diverse community comprising savannah and forest species, including endemics (Barbosa et al., 2007). They are highly threatened by expanding large-scale agriculture, and large tracts have already been converted for cultivation of soya, rice, eucalyptus and pine, and cattle ranching (Carvalho \& Mustin, 2017). These enclaves are poorly studied, particularly compared to other cerrado areas (Carvalho \& Mustin, 2017). Here, we report the discovery of populations of pampas deer Ozotoceros bezoarticus in savannah enclaves located in the Arc of Deforestation, an area of rapid agricultural expansion along the southern border of Brazilian Amazonia, $350 \mathrm{~km}$ beyond the species' formerly presumed distribution.

The pampas deer is a medium sized $(20-40 \mathrm{~kg})$, predominantly diurnal cervid of Neotropical open grasslands and shrublands (Rodrigues \& Monteiro-Filho, 1999). Its historical range encompassed extensive open habitats in Argentina, Uruguay, Paraguay, Bolivia and central Brazil, but as a result of expansion of agriculture its habitat has been drastically reduced and fragmented (Weber \& Gonzalez, 2018). Once considered the most threatened South American cervid (González, 1998), the pampas deer is currently categorized as Near Threatened on the IUCN Red List (González et al., 2016). In Brazil, the country that holds most of the pampas deer's current range, the species is categorized as Vulnerable (Duarte et al., 2012). Five subspecies of pampas deer are recognized (González et al., 2002), and most of the extant populations, except those in the Pantanal and the northeastern Brazilian cerrado, are estimated to be $<1$,000 individuals, with a decreasing trend (González et al., 2016). Range-wide, the main threats to the species are habitat 
loss and fragmentation, hunting and emerging diseases (González et al., 2016).

Our study area encompasses $70,000 \mathrm{~km}^{2}$ in the Brazilian states of Amazonas and Rondônia. The landscape comprises a mosaic of land-cover types, including continuous Amazon forest, open savannah enclaves (grasslands and bushlands), transitional forest-savannah areas and human-impacted forest with different degrees of fragmentation. The climate in the region is tropical humid, with mean monthly temperatures of $24-28^{\circ} \mathrm{C}$ and mean annual precipitation of $2,060-$ $2,890 \mathrm{~mm}$. There is a rainy season from October to March and a dry season from April to September (ICMBio, 2011).

As part of a wildlife survey during February 2016-June 2017, we installed camera traps at 64 open savannah and transitional forest-savannah sites, which had not previously been systematically surveyed for mammals, within the Campos Amazônicos and Mapinguari National Parks, in locations that had signs of medium-sized or large mammals (Fig. 1b; Supplementary Table 1). Each site had one unbaited camera trap (PC8oo Hyperfire, Reconyx, Holmen, USA). Cameras were continuously active for a mean of 66.7 days, for a total of 4,274 camera-trap days. We estimated the size of the potential pampas deer habitat in the study area by calculating the total area of savannah and savannah-steppe habitat classes, following the Biomes Vegetation Cover map for Brazilian Amazonia (MMA, 2018).

Our camera-trap survey yielded 23 independent records (photos at the same site were considered independent when at least one hour apart; Meek et al., 2014) of pampas deer (Supplementary Table 2, Supplementary Plate 1), resulting in a trapping success of 0.54 records/100 camera-trap days. We detected the species at nine camera traps in open savannah sites, within three enclaves. Ten of the records were of females, nine of males, and we could not determine the sex for four records. Twenty records (86\%) were between sunrise and sunset, and only three were of more than one individual. We also sighted pampas deer, including fawns, opportunistically on several occasions during fieldwork within the savannah enclaves. Our data did not allow us to estimate population size, density or other demographic parameters.

The protected areas and savannah enclaves with newly confirmed populations of pampas deer lie outside the species' previously presumed historical range, at least $350 \mathrm{~km}$ from any previously known extant population (Fig. 1a). Together, the savannah enclaves with confirmed pampas deer records add c. 4,00o $\mathrm{km}^{2}$ to the known range of the species (Table 1), and unsurveyed enclaves in this region represent an additional $2,500 \mathrm{~km}^{2}$ of potential pampas deer habitat.

The savannah enclaves we surveyed are not connected. Dating of carbon isotopes from our study area indicates that vegetation cover has been relatively stable for at least the past 9,000 years (Gomes, 2016), suggesting that pampas deer populations in these enclaves may have been isolated for a long time. It is likely that current gene flow between

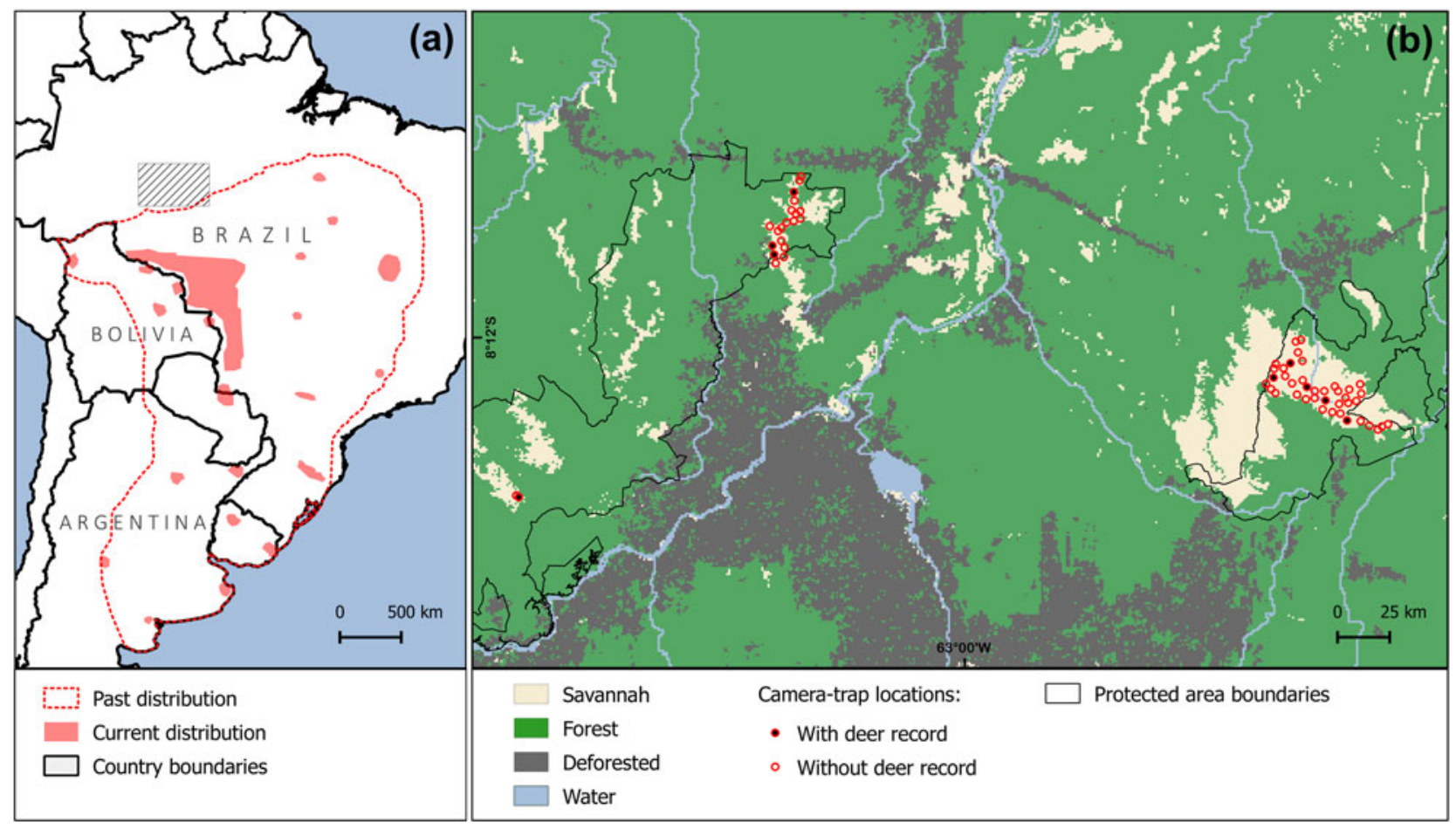

FIG. 1 (a) Location of the study area, with past and present distribution of the pampas deer Ozotoceros bezoarticus. (b) Camera-trap locations, with and without pampas deer records, within savannah enclaves in the southern Brazilian Amazonia. 
TABLE 1 The three southern Amazonia savannah enclaves (Fig. 1) surveyed with camera traps, with the surveyed area, number of camera-trap sites (each of which had one camera trap) and number of records of pampas deer Ozotoceros bezoarticus.

\begin{tabular}{llll}
\hline $\begin{array}{l}\text { Surveyed } \\
\text { savanna enclave }\end{array}$ & $\begin{array}{l}\text { Area } \\
\left(\mathrm{km}^{2}\right)\end{array}$ & $\begin{array}{l}\text { No. of camera- } \\
\text { trap sites }\end{array}$ & $\begin{array}{l}\text { Pampas deer } \\
\text { records }\end{array}$ \\
\hline Eastern & 2997.1 & 40 & 15 \\
Central & 572.2 & 19 & 7 \\
Western & 369.3 & 5 & 1 \\
\hline
\end{tabular}

enclaves is low, given that our extensive camera trapping in nearby forests did not record the species (unpubl. data for $>10,000$ camera trap-days). Genetic studies of the pampas deer in this area could provide information on the meta-population dynamics of the species, and on any genetic differentiation between populations in different enclaves and in relation to populations beyond Amazonia (it is not yet known to which of the five pampas deer subspecies the Amazonian savannah populations belongs).

Although this is the first scientific account of the pampas deer in the southern Amazonian savannahs, local farmers and settlers have long known the species to exist there (pers. comms to ARD, WRCA and BCC), and report that it was more abundant before the influx of people into this region during the 1970s. Any decline would not be unexpected given the extensive threats that wildlife face in the Arc of Deforestation. Because the population trend is probably negative and populations are presumed to be small and isolated, ensuring the persistence of these newly recorded pampas deer populations may require management. This highlights the need for more detailed studies on pampas deer demography and connectivity in these enclaves to assess the species' conservation status and inform management. Most of the southern Amazonia savannah enclaves lie within protected areas; the presence of the Vulnerable pampas deer reinforces the need for protection. Given that a medium-sized mammal species such as the pampas deer was unrecorded by the scientific community until recently, it is possible that the enclaves harbour other elusive and/or threatened species. Unfortunately, being within a federal protected area does not guarantee security. The boundaries of both Mapinguari and Campos Amazonicos national parks were altered in 2010 and 2012, respectively, to accommodate infrastructure developments such as highways and hydroelectric dams, and other infrastructure projects are being considered in this region.

Our study meets some of the research requirements for the pampas deer listed by IUCN and the Brazilian national assessment for the species, particularly the search for new populations and as a contribution to the management of protected areas (Duarte et al., 2012; González et al., 2016). As well as establishing that the range of the pampas deer is greater than previously presumed, our study highlights the need for further studies, particularly genetic, to assess the conservation status of these enclave populations, the results of which could potentially inform management decisions in other areas of the heavily fragmented range of this species.

Acknowledgements We thank Instituto Mamirauá, and Campos Amazônicos and Mapinguari National Parks for logistical and financial support. We thank França, Wesley, Finicius, Edinaldo, Antônio, Leandro and the many others who helped in the field. DGR received a scholarship from the CAPES/Doutorado Pleno no Exterior (\#88881.128140)

Author contributions Study design and data collection: DGR, DMG, WRCA, BCC, ARD and AEP; interpretation of results and writing: DGR, RS and AV; revision: all authors.

\section{Conflicts of interest None.}

Ethical standards This research abides by the Oryx guidelines on ethical standards. Survey permits were granted by ICMBio/SISBIO (52720-1, 54457-1).

\section{References}

Barbosa, R.I., Campos, C., Pinto, F. \& Fearnside, P.M. (2007) The 'Lavrados' of Rroraima: biodiversity and conservation of Brazil's Aamazonian savannas. Functional Ecosystems and Communities, 1, 29-41.

Cardoso Da Silva, J.M. \& Bates, J.M. (2002) Biogeographic patterns and conservation in the South American cerrado: a tropical savanna hotspot. BioScience, 52, 225-234.

Carvalho, W.D. \& Mustin, K. (2017) The highly threatened and little known Amazonian savannahs. Nature Ecology \& Evolution, 1, o10o.

Duarte, J.M.B., Vogliotti, A., dos Zanetti, E. S., De Oliveira, M.L., Tiepolo, L.M., Rodrigues, L.F. et al. (2012) Avaliação do risco de extinção do veado-campeiro Ozotoceros bezoarticus Linnaeus, 1758, no Brasil. Biodiversidade Brasileira, 2, 20-32.

Gomes, F.B. (2016) Dinâmica paleoambiental holocênica no enclave de savana em meio a floresta situado nos setores Tabajara e Estanho do Parque Pacional Campos Amazônicos $(A M / R O)$. PhD thesis. Universidade Federal do Paraná, Curitiba, Brazil.

GonZÁlez, S. (1998) Estado de conservação dos cervídeos da América do Sul. Logos Tempo e Ciência, 2, 61-65.

GonzÁlez, S., Álvarez-Valin, F. \& Maldonado, J.E. (2002) Morphometric differentiation of endangered pampas deer (Ozotoceros bezoarticus), with description of new subspecies from Uruguay. Journal of Mammalogy, 83, 1127-1140.

GonZÁlez, S., Jackson, III, J.J. \& Merino, M.L. (2016) Ozotoceros bezoarticus. In The IUCN Red List of Threatened Species 2016: e.T15803A2216003o. Http://dx.doi.org/10.2305/IUCN.UK.2016-1. RLTS.T15803A22160030.en [accessed 15 January 2019].

iCMBio (Instituto Chico Mendes de Conservação da Biodiversidade) (2011) Plano de Manejo-Parque Nacional dos Campos Amazônicos. Instituto Chico Mendes de Conservação da Biodiversidade, Brasília, Brazil.

Meek, P.D., Ballard, G., Claridge, A., Kays, R., Moseby, K., O'Brien, T. et al. (2014) Recommended guiding principles for 
reporting on camera trapping research. Biodiversity and Conservation, 23, 2321-2343.

ma (Ministério do Meio Ambiente) (2018) Mapas de Cobertura Vegetal dos Biomas Brasileiros. Ministério do Meio Ambiente, Brasília, Brazil. Http://mapas.mma.gov.br/mapas/aplic/ probio/datadownload.htm [accessed 20 August 2008].

Myers, N., Mittermeier, R.A., Mittermeier, C.G., Fonseca, G.A.B. \& Kent, J. (2000) Biodiversity hotspots for conservation priorities. Nature, 403, 853-858.
Rodrigues, F.H.G. \& Monteiro-Filho, E.L.A. (1999) Feeding behaviour of the pampas deer: a grazer or a browser. Deer Specialist Group News, 15, 12-13.

Strassburg, B.B.N., Brooks, T., Feltran-Barbieri, R., Iribarrem, A., Crouzeilles, R., Loyola, R.D. et al. (2017) Moment of truth for the Cerrado hotspot. Nature Ecology \& Evolution, 1, 0099.

Weber, M. \& Gonzalez, S. (2018) Latin American deer diversity and conservation: a review of status and distribution. Écoscience, 11, $163-184$. 